\section{ADVANCES IN VIROLOGY}

Perspectives in Virology

Vol. 2. Edited by Morris Pollard. Pp. $x+220$. (Minneapolis, Minn.: Burgess Publishing Company, 1961. Published for the Gustav Stern Foundation of Now York.). 8 dollars.

$\checkmark$ HIS volume contains nineteen papers presented at a symposium sponsored by the Gustav Stern Foundation and held in New York in February 1960. This was the fourth of such symposia and the second bearing the title Perspectives in Virology. There was special honour paid to Dr. Peyton Rous, to celebrate his eightieth birthday and the fiftioth anniversary of his first account of the Rous sarcoma. There is a most excellent and sympathetic tribute to him by Charles Oberling; and six of the subsequent papers deal with tumour viruses.

Other papers, all by acknowledged authorities. deal with the kappa particles of Paramecium (Sonneborn), mutagenesis in vitro (Schramm), aspects of adenovirus infection (Ginsberg; Schlesinger), of poliomyelitis (Darnell; Sabin), search for antiviral agents (Waksman), interferon (Isaacs). There are more and more of these symposia with proceedings published afterwards; and naturally many papers tend to contain a re-hash of previously published work. Some of the participants do present more general reviews, as do Robley Williams on "Viruses and Virus-like Particles" and Kibrick on "Viral Infections of the Foctus and Newborn".

There is not one of these papers which does not contain much information of interest, the facts boing well documented with tables and some illustrations. One naturally asks, however, for whom the book will be useful. Not for the research worker who is himself in the swim: he can go readily to other more detailed sources. Not for the average medical man: the work is far too technical. It is rather for the teacher or advanced student in microbiology or a related field who wants to know where the advancing edge of research in virology is reaching out.

The first Perspectives in Virology, published two years ago, was in a handy, nicely bound volume pleasantly printed on excellent paper. Vol. 2 is in a loss handy size $\left(11 \frac{1}{2} \times 8 \frac{3}{4}\right.$ in. $)$ in a rougher binding with paper and printing of a far less satisfactory character. Perhaps the producors of the book can scarcely be blamed; the volume is necessarily one of rather ephemeral value, so they may feel it wise to knop the price as low as they can.

Christopher Andrewes

\section{CHEMISTRY OF FOOD AND NUTRITION}

A Chemical Approach to Food and Nutrition

By Brian A. Fox and Allan (G. Cameron. Pp. 326. (London: University of London Press, I.td., 1961.) $30 s$. net.

THE study of food and nutrition ean be both an art and a science, and, as the authors so rightly state in their preface, there is a dearth of good text-books dealing with theso subjects, from a chemical point of view, at an elementary level. This book makes good the deficiency.

Although it is assumed that the reader has some knowledge of chemistry, two chapters are devoted to the nature of atoms and molecules, and to the chemistry of certain substances that are fundamental to the study of nutrition.

Thence follow chapters on each important nutrient, including oils and fats; carbohydrates 1, sugars; carbohydrates 2, polysaccharides; nitrogon compounds; water and mineral elements and vitamins. The chemical nature of these nutrients is elucidated, their digestion and absorption described and their role in the body defined. In addition, the effects of a deficiency are given and, where known, the human requirement of each nutrient.

Throughout these chapters are given details of the manufacture of certain staplo foodstuffs, including bread and flour, margarine, alcoholic beverages, vinogar and sugar products.

Chapter 13 gives details of the composition of some important foods such as milk, butter, cheese, eggs and fish and the effect of cooking.

The final chapter describes the various methods of food preservation, and includes particulars of preserva. tion with antibiotics, at present forbidden in Great Britain, and sterilization by radiation, a method still in its experimental stage. I was pleased to see an account of the contamination of food by radioactive materials, a subject so very pertinent at the present time.

Reference to the original sources of material in the book are not given as the authors feel that this would greatly increase the cost of the book and be useful to fow readers. However, at the end of each chapter is given a list of references for further reading and at the end of the book a general reading list of relevant books, some of which are more advanced than the present one. A list of films that could be used in conjunction with this text is a useful addition for the teacher.

As a basic text-book outlining an enormous field I can recommend this book for students of olementary nutrition, domestic science and catering; but I have doubts of its claim to be of value to the medical student.

A. M. Brown

\section{X-RAY CRYSTALLOGRAPHY}

Direct Methods in Crystallography

By M. M. Woolfson. (Monographs on the Physics and Chemistry of Materials.) P'p. viii + 144. (Oxford : Clarendon Press; London: Oxford Unirersity Pross. 1961.) 30s. net.

THE title of this book is rather misleading, since the subject concerns X-ray, not classical. erystallography, and, in particular, crystal structure analysis from the stage at which a set of structure amplitudes has been collected to the location of the most probable atomic positions. The problem is, of course, to determine the phases or signs of these structure amplitudes, and the usual procedure was more or less to 'guess' these by various indirect methods, often involving some specific knowledge about the structure. During the past ten years or so it has been realized that considerations of a very general kind (for example, that the electron density is positive or is confined to small similar regions around the atomic contres) are of themselves sufficient to imposo limitations on, or even give rolations between, the phases (usually signs) and the magnitudes of the structure factors.

This monograph is the first eomprehensive account to appear of these new developments, and its purpose 